\title{
THE IMPLEMENTATION EFFECTIVENESS OF HOSPITAL RESPONSIBILITY TOWARDS HEALTHCARE WORKERS IN COVID19 ERA AT HOSPITAL X SUKABUMI
}

\author{
Susilo Kurniawan Yeo ${ }^{1}$ \\ Esa Unggul University \\ yeo.susilo@gmail.com \\ Andry ${ }^{2}$ \\ Esa Unggul University \\ Ratna Indrawati ${ }^{3}$ \\ Esa Unggul University
}

\begin{abstract}
Since the Coronavirus Disease 2019 (COVID-19) pandemic occurred in Indonesia, the health workers have become both an important entity in fighting COVID-19 and has high risk of being exposed to COVID-19. They required high protection for their safety. This work aimed to describe the applicable laws and regulations in Indonesia regarding the responsibility of Hospitals to Healthcare Workers in the COVID-19 Era and to test the effectiveness of regulation implementation. A phenomenological study approach was applied in this study. The thematic analysis was conducted to obtain the main theme of this study. The results revealed six laws and regulations were related to the hospitals' responsibility toward healthcare workers which were Law number 36 of 2009 concerning Health, Law number 44 of 2009 concerning Hospitals, Government Regulation Number 88 of 2019 concerning Occupational Health, Minister of Health Regulation number 66 of 2016 concerning Hospital Occupational Health and Safety, Minister of Health Decree number 413 of 2020 concerning Guidelines for the Prevention and Control of Coronavirus Disease 2019, and Decree Number 392 of 2020 concerning Incentives and Death Compensation for Healthcare Workers.
\end{abstract}

Keywords: COVID-19, Healthcare Worker, Hospital, Responsibility 


\section{A. Introduction}

On December 29, 2019, at a hospital in Wuhan, Hubei Province, China, it was reported that an unknown disease had developed pneumonia. The PRC government then informed the World Health Organization (WHO) about the emergence of this disease after going through a verification process. Then on January 8, 2020, the pathogen from this incident could be identified as the 2019 Novel Coronavirus (nCoV-2019), and its gene structure was immediately sent to WHO. On January 30, 2020, it was declared the emergence of the Novel Coronavirus Pneumonia (NCP) as Public Health Emergency of International Concern (PHEIC). ${ }^{1}$ Then on February 12, 2020, the International Committee on Taxonomy of Viruses (ICTV) declared that nCoV-2019 became the official name of the Severe Acute Respiratory Syndrome Coronavirus 2 ((SARS-CoV-2), and on the same day WHO declared SARS-CoV- 2 official names are Corona Virus Disease 2019 (COVID-19). ${ }^{2}$

COVID-19 has been declared by WHO as a Global Pandemic on March 11, 2020, and the Government of Indonesia based on Presidential Decree No.11 of 2020 concerning Determination of Public Health Emergencies Corona Virus Disease 2019 has declared COVID-19 as a public health emergency for which prevention efforts must be made. Then on April 13, 2020, the Government also issued another Presidential Decree regarding the stipulation of COVID-19 as a National Disaster. The people most at risk of infection are those who are in close contact with COVID-19 patients or who care for COVID-19 patients. Healthcare workers at the forefront of the COVID-19 pandemic response are at greater risk of exposure to infection. ${ }^{3,4}$ It is proven that on April 13, 22 doctors, 6 dentists, and 10 nurses had died from COVID-19 in Indonesia. ${ }^{5}$

The vicarious liability theory implies that the employer is responsible for the other party's losses incurred by the person or employee under their supervision. ${ }^{6}$ Corporate liability theory has the same meaning as vicarious liability. According to this doctrine, the institution which houses a group of workers has responsibility for the labor it employs. ${ }^{7}$ Another theory regarding accountability is the gevaarzetting theory which teaches that a person who asks for help from a third party to do an action for him must be brave to take the risk of his actions in the work for which they are used.5 There is also Shared Responsibility Theory which means that cooperation between workers and employers is the best way to reduce occupational incidents. ${ }^{8}$ Occupational safety and health are instruments that protect workers, companies, the environment, and the surrounding community from the dangers of work accidents. This protection is a human right that must be fulfilled by the company. ${ }^{9}$ 
The Implementation Effectiveness of Hospital Responsibility Towards Healthcare Workers in...

In Health Law No. 36 of 2009, Article 165 states that workplace managers are required to make all forms of health efforts through prevention, improvement, treatment, and recovery for workers. Besides, the following article also states that employers or employers are obliged to guarantee the health of workers through prevention, improvement, treatment, and recovery and are required to bear all costs of health care for workers and also costs for work-related health problems suffered by workers under statutory regulations. ${ }^{10}$ In Hospital Law Number 44 of 2009, specifically in Article 3 paragraph 2 states that the purpose of running a hospital is one of which is to protect the safety of patients, the community, the hospital environment, and human resources in the hospital; but it does not specifically regulate how the form of hospital responsibility to healthcare workers who are human resources who work in the hospital environment, especially in the era of COVID-19. ${ }^{11}$ Based on the explanation above, this study aims to determine the responsibility of hospitals toward healthcare workers, especially in the era of the COVID-19 pandemic from a juridical perspective.

We conducted a qualitative study using documentary studies to identify the law and regulation concerning hospitals' responsibility towards healthcare workers in this COVID-19 Pandemic situation and also conducted in-depth interviews to identify the implementation of the laws and regulations at one of the hospitals in Indonesia, which is hospital X Sukabumi. A better understanding of the laws and regulations could help hospitals in carrying out their obligations and maintain the rights of the healthcare workers, especially the right to be in good health in this pandemic situation.

\section{B. Method}

A qualitative study was conducted by documentary study and also in-depth interviews between 15 July 2020 and 15 August 2020. The study took place at Hospital X in Sukabumi district, West Java Province, Indonesia. This hospital was chosen because it also serves COVID-19 patients daily and has also been appointed as a Referral Hospital for Certain Emerging Infectious Diseases in West Java Province. Each participant has explained the purpose of the study and asked to sign the informed consent form to allow tape recording during the in-depth interview process.

\section{a. Population and Samples}

The study population was comprised of those who were directly involved in serving COVID-19 patients daily at Hospital X, Sukabumi, Indonesia. The two main groups of the study population were the hospital management and the healthcare workers who are 
working together at Hospital X, Sukabumi in handling COVID-19 patients. Samples included 4 key informants purposively selected as informants by the researcher as they could give valuable insights into this research. The first group comprised 2 key informants mainly the director of hospital X, Sukabumi, and the head of the human resource department. The second group included a member of the hospital occupational health unit and also the head of the emergency department, both were also healthcare workers at Hospital X Sukabumi, Indonesia.

\section{b. Data Collection Procedure}

The documentary studies were conducted to obtain or search for concepts, theories, principles, and other ideas related to research problems. The documentary study carried out includes research on documentation carried out by studying various regulations, cases, and documents that are related to research problems.

In-depth interviews were conducted by using a semi-structured interview, with open-ended questions following an interview guideline. Each interview took place at a hospital X Sukabumi for approximately 30-60 minutes. All interviews were audiotape recorded and were transcribed by the interviewer. The interview guidelines were classified into two sub-groups of key informants as follows: (1) hospital management included the themes of laws and regulation related to hospital's obligation toward healthcare workers, implementation of the laws and regulation; (2) healthcare workers included the themes of perceived support from the hospital, implementation of the laws and regulation. Before research was conducted, three experts checked the interview guidelines. A detailed explanation of the themes explored by each sub-group of key informants is summarized in Table 1.

Table 1 Description of sample selection and number of samples enrolled in each group

\begin{tabular}{|c|c|c|c|}
\hline Participants & $\begin{array}{l}\text { Sample } \\
\text { Size }\end{array}$ & Selection Criteria & Themes \\
\hline $\begin{array}{l}\text { Hospital } \\
\text { Management }\end{array}$ & 2 & $\begin{array}{l}\text { - Has been working as the } \\
\text { hospital management } \\
\text { team } \\
\text { - Worked least } 1 \text { year }\end{array}$ & $\begin{array}{l}\text { - Laws and regulation } \\
\text { related to hospital's } \\
\text { obligation toward } \\
\text { healthcare workers } \\
\text { - Implementation of the } \\
\text { laws and regulation }\end{array}$ \\
\hline $\begin{array}{l}\text { Healthcare } \\
\text { Workers } \\
(\mathrm{HCW})\end{array}$ & 2 & $\begin{array}{l}\text { - Serves COVID-19 } \\
\text { patients daily } \\
\text { - Worked at least } 1 \text { year }\end{array}$ & $\begin{array}{l}\text { - Perceived support from } \\
\text { hospital } \\
\text { - Implementation of the } \\
\text { laws and regulation }\end{array}$ \\
\hline
\end{tabular}




\section{Finding and Discussion}

\section{Finding}

By documentary studies, we found that there were at least 6 laws and regulation related to hospital's obligation toward healthcare workers namely Law number 36 of 2009 concerning Health, Law number 44 of 2009 concerning Hospitals, Government Regulation Number 88 of 2019 concerning Occupational Health, Minister of Health Regulation number 66 of 2016 concerning Hospital Occupational Health and Safety, Minister of Health Decree number 392 of 2020 concerning Incentives and Death Compensation for Healthcare Workers and lastly Decree Number 413 of 2020 concerning Guidelines for the Prevention and Control of Coronavirus Disease 2019. From there on we found five relevant themes that were to be discussed to see the implementation of the laws and regulations at Hospital X Sukabumi.

\section{a. Organizing education and training for human resources}

This was required by Law number 44 of 2009 Article 5 Letter C which states that in carrying out the task of providing comprehensive health services, the hospital has a function in providing education and training for human resources in the context of increasing the ability to provide health services. In the era of COVID-19, the ability to provide different health services is needed. It takes more knowledge and skills than the era before COVID-19.

And also from the Minister of Health Decree Number 413 of 2020 concerning Guidelines for the Prevention and Control of Coronavirus Disease 2019, Hospitals are recommended to provide training education to all hospital staff about COVID-19 with materials such as epidemiological triangle, chain of infection, the concept of infection, infection prevention and control program, isolation precautions, the concept of COVID19, personal protective equipment, occupational health and safety and also waste management.

During the interview, The Director of the Hospital and also the Human Resources Division expressed that Hospital X Sukabumi has conducted education and training for human resources to increase the ability to provide health services. However, healthcare workers do not agree that RS X Sukabumi has conducted education and training for them because what Hospital $X$ Sukabumi has been doing is an only notification by internal memo,

"Yes, we have organized education and training for our healthcare workers because according to the guidelines for prevention and control of COVID-19, training 
must be held. However, the training is only through internal memos" (Director, Male, 35years-old).

"If it is meant by face-to-face training and education, then it has not been conducted, because we only got the info through leaflets and internal memos" (HCW, Female, 28-years-old).

\section{b. Carrying out occupational health standards}

Through Government Regulation Number 88 of 2019 concerning Occupational Health concerning the working standards set by the Government, it can be seen that hospitals as managers of workplaces are required to meet occupational health standards which have been established by the Government through efforts to prevent disease, improve health, treat disease and also restore health from health workers who have a high risk of infection.

During the interview with the informants, Hospital X Sukabumi has made efforts to prevent disease by carrying out the occupational health standards by the Government, such as the prevention standards and the treatment standards. But Regarding the standards related to health improvement as in Article 5 has not been implemented which were the implementation of work nutrition and also improvement of mental health. And regarding health recovery standards for healthcare workers have not been fully implemented.

"Only during this pandemic, there was a provision of vitamin C as extra food. But before that we have no program regarding work nutrition." (HCW, Female, 30-years-old).

"The hospital provides regular treatment, but regarding mental health, we have no such program." (HCW, Female, 28-years-old).

“We haven't experienced cases that needed the recovery health program, we only provide regular treatment." (Director, Male, 35-years-old).

\section{c. Organizing Hospital Occupational Health and Safety (HOHS)}

Through the Regulation of the Minister of Health of the Republic of Indonesia Number 66 of 2016 concerning Hospital Occupational Health and Safety (HOHS) concerning the hospital's responsibility for health workers, it can be seen that the Hospital is obliged to implement HOHS following article 3 which includes Hospital Occupational Health and Safety Management System in article 4 and the HOHS standards listed from articles 7 to 19 , besides that it is also required to have a HOHS functional unit and conduct HOHS evaluations every 6 months to protect the safety and health of hospital human resources as well as protection of patients, patient companions, visitors, 
The Implementation Effectiveness of Hospital Responsibility Towards Healthcare Workers in...

and the hospital environment so that a healthy, safe, secure and comfortable hospital condition can be created, especially in this COVID-19 era.

During the interview with informants, Hospital X Sukabumi has organized HOHS which includes the Hospital Occupational Health and Safety Management System as well as the HOHS standards. However, they failed at promotional activities such as the fulfillment of work nutrition and mental and spiritual guidance. Apart from that the return to work program which is not yet available according to the hospital director.

Related to the HOHS functional unit which should be led by health workers with the lowest qualifications of bachelor degree in the field of Occupational Safety and Health, or other health workers with the lowest qualifications of a bachelor who have competence in the field of HOHS are not yet available at Hospital X Sukabumi. This is because the doctor who previously served is no longer working at Hospital X Sukabumi, and until now there is still no replacement, but the evaluation of $\mathrm{HOHS}$ is still conducted by the HOHS unit member.

"There is no return to work program yet" (Director, Male, 35-years-old).

"Yes, the previous doctor who worked (as head of the HOHS department) here has already retired and since then we have not yet found the replacement." (HR, Female, 38years-old).

\section{d. Infection control and prevention}

As what stated in Decree Number 413 of 2020 concerning Guidelines for the Prevention and Control of Coronavirus Disease 2019 whereas to minimize the risk of exposure to the SARS-CoV-2 virus to healthcare and non-healthcare workers, patients, and visitors to health care facilities, it is necessary to observe the principles of prevention and control of the risk of transmission as implementing isolation precautions for all patients, implementing administrative control and also conducting education and training.

Isolation precautions such as conducting screening at the entrance to the admission room for new patients, a separation between patients with respiratory system disorders and those without respiratory system disorders, putting special markers to set a minimum distance of 1 meter at the queuing locations for patients/visitors., creating a physical barrier (barrier) between officers and visitors, adjusting the position of the consultation table, examination bed and patient chair with health personnel which that prevent airflow from the patient to the examiner/officer, placing positive or suspected cases in the Isolation room 
Regarding the application of administrative control as intended, among others is to ensure the implementation of keeping a minimum distance of 1 meter can be applied in all areas of health facilities, to prohibit visitors and watchmen for adult patients with suspected cases, probable cases, or positive confirmed cases of COVID-19, organizing Personal Protective Equipment (PPE) logistics so that supplies are used properly and creating a policy on health and protection of hospital healthcare workers.

During the interview with hospital management, Hospital $X$ has done what is written in the guidelines given by the government. This is proved by the existence of internal guidelines made by Hospital X Sukabumi which refer to the minister of health decree regarding the COVID-19 guidelines. And during an interview with the healthcare workers, they also agreed that infection control and prevention have been carried out such as implementing isolation precautions and administrative controls.

"Yes, we have done the infection control and prevention by the guidelines issued by the Minister of Health." (Director, Male, 35-years-old).

"Regarding that (Isolation precautions and administrative controls) have been applied to start from hand hygiene, PPE, respiratory hygiene, environmental hygiene, linen handling, waste management, disinfection of patient care equipment, safe injecting practices, etc" (HCW, Female, 30-years-old).

\section{e. Facilitating incentives from the government}

To give appreciation and appreciation to health workers who handle Corona Virus Disease 2019 (COVID-19) in Indonesia, the Government provides incentives and death benefits for Healthcare Workers who handle Corona Virus Disease 2019 (COVID-19). It should be noted that health workers who are under private hospitals that receive incentives and death benefits are those who provide services in the COVID-19 isolation room, high care unit/ intensive care unit at the COVID-19 room and emergency department which was regulated under Minister of Health Decree number 392 of 2020 concerning Incentives and Death Compensation for Healthcare Workers.

Concerning the hospital's responsibility for healthcare workers is found in this Ministerial Decree. This can be seen in the formation of a verification team at health service facilities, which states that the verification team for health service facilities or health institutions that submit proposals for incentives for health workers to the District /City Regional Health Office, with elements consisting of at least Internal Supervisory Unit, Element of service in health service facilities or health institutions, Elements of management of health service facilities or health institutions. 
The Implementation Effectiveness of Hospital Responsibility Towards Healthcare Workers in...

The duties of the verification team for health service facilities or health institutions that submit proposals for incentives for health workers to the District / City Regional Health Office include verifying and validating the required documents, making notes on the results of verification and validation if necessary; and lastly is to submit recommendations on the results of verification and validation to the Head of District/City Health Service.

Based on the interview conducted, Hospital X Sukabumi has formed a verification team and has also made recommendations to the local government. However, until this research was conducted, this incentive had not yet been realized.

"Yes, we have formed a verification team, and have also made a recommendation to the local health office, but I heard is that the incentive has not been issued." (Director, Male, 35-years-old).

"The hospital has asked us for data. However, we have not received incentives until now." (HCW, Female, 28-years-old).

Table 2 shows the implementation of hospital responsibility towards healthcare workers in COVID-19 based on Indonesian laws and regulations. Five themes were obtained from this study including (1) Organizing education and training for human resources, (2) Carrying out occupational health standards, (3) Organizing Hospital Occupational Health and Safety, (4) Infection control and prevention, (5) Facilitating incentives from the government.

Table 2 Implementation of Hospital X Responsibility Towards Healthcare Workers In COVID-19 based on Indonesian Laws and Regulations

\begin{tabular}{|l|l|}
\hline \multicolumn{1}{|c|}{ Categories of Themes } & \multicolumn{1}{c|}{ Sub-Theme Categories } \\
\hline $\begin{array}{l}\text { Organizing education and training } \\
\text { for human resources }\end{array}$ & $\begin{array}{l}\text { Partially conducted } \\
\text { Education and Training only through internal } \\
\text { memos }\end{array}$ \\
\hline $\begin{array}{l}\text { Carrying out occupational health } \\
\text { standards }\end{array}$ & $\begin{array}{l}\text { Implemented prevention standards and } \\
\text { treatment standards. } \\
\text { Health improvement standards have not yet } \\
\text { been implemented. } \\
\text { Health recovery standards for healthcare } \\
\text { workers have not been fully implemented. }\end{array}$ \\
\hline $\begin{array}{l}\text { Organizing Hospital Occupational } \\
\text { Health and Safety (HOHS) }\end{array}$ & $\begin{array}{l}\text { Implemented HOHS partially } \\
\text { No work nutrition and mental and spiritual } \\
\text { program } \\
\text { No return to work program }\end{array}$ \\
\hline
\end{tabular}




\begin{tabular}{|l|l|}
\hline & Vacant position as head of HOHS unit \\
\hline Infection control and prevention & $\begin{array}{l}\text { Have implemented the isolation precaution } \\
\text { Have implemented the administrative controls }\end{array}$ \\
\hline $\begin{array}{l}\text { Facilitating incentives from the } \\
\text { government }\end{array}$ & $\begin{array}{l}\text { Have formed a verification team } \\
\text { Have submitted a recommendation to the local } \\
\text { health office }\end{array}$ \\
\hline
\end{tabular}

\section{Discussion}

Hospitals have specific occupational safety and health risks so they need to be managed properly so that they can become a healthy, safe, and comfortable workplace, especially in this era of COVID-19. Therefore, a commitment from the Head or Director of the Hospital as manager of the workplace is required to implement the applicable laws and regulations related to the Hospital's responsibility to the Health Workers who work in the hospital.

Through our findings, we identify several laws and regulations can be a source of reference regarding the responsibilities of Hospitals for Healthcare Workers in the Era of COVID-19 in Indonesia, including Law Number 44 of 2009 concerning Hospitals, Law Number 36 of 2009 concerning Health, Government Regulation of the Republic of Indonesia Number 88 of 2019 concerning Occupational Health, Regulation of the Minister of Health of the Republic of Indonesia Number 66 of 2016 concerning Hospital Occupational Health and Safety, Decree of the Minister of Health of the Republic of Indonesia Number HK.01.07/Menkes /413/2020 concerning Guidelines for the Prevention and Control of Coronavirus Disease 2019 (COVID-19), Decree of the Minister of Health of the Republic of Indonesia Number HK.01.07/Menkes /392/2020 concerning the Providing of Incentives and Death Compensation for Healthcare workers Handling Corona Virus Disease 2019 (COVID-19).

Therefore, it is hoped that the workplace manager, in this case, the hospital or hospital leadership, can refer to these regulations regarding what hospitals should do with health workers in this era of COVID-19. Because after all, COVID-19 not only causes death but also causes considerable economic loss, so knowledge is needed in carrying out prevention efforts including prevention and control by protecting health workers on duty.

Conducting education and training for human resources is required by law to increase the ability to provide the need for health services. However, Hospital $X$ Sukabumi has not been fully implemented. The connection with education and training 
The Implementation Effectiveness of Hospital Responsibility Towards Healthcare Workers in...

on COVID-19 must be carried out properly because without good and correct knowledge about this pandemic it can have serious implications not only for health workers but also for hospitals. Few studies suggested that healthcare workers surveyed during emerging infectious disease times demonstrated a lack of knowledge surrounding these pathogens and a need for further education/training. ${ }^{12,13}$ Outbreaks of novel pathogens can be extremely stressful to healthcare workers, but this stress can be lessened by clear guidelines from hospitals and IPC teams. ${ }^{14}$

Regarding occupational health standards that are provided by the Indonesian Government such as prevention, health improvement, treatment, and health recovery standards, Hospital $X$ only manages to implement disease prevention and treatment standards. However, health improvement and health recovery standards have not been fully implemented. For health workers who are sick due to work-related accidents or are exposed to occupational diseases, in this case being infected with COVID-19, a return to work assistance program is needed. The goal is to ensure that health workers can return to work according to their previous function, but if they cannot return to work, then it can be considered to be transferred to another place so that services to patients can also be served properly. Hospitals are required to carry out rehabilitative activities, namely by establishing a return to work assistance program for hospital human resources who experience limitations after experiencing illness for more than 2 weeks. ${ }^{15}$

Regarding Organizing Hospital Occupational Health and Safety (HOHS), hospital X has Implemented HOHS partially, in which there is no work nutrition and mental and spiritual program and also return to work program. One main focus is that there is still a vacant position as head of the HOHS unit at the hospital. It is feared that the hospital environment will become unsafe not only for health workers but also for patients and their families because no one is responsible for implementing HOHS at the Hospital X Sukabumi.

Incentives from the government aimed towards those who serve COVID-19 on daily basis and also for death benefits for those deceased while serving COVID-19 patients, where hospital responsibility is to verify the data and submit the recommendation has already been done by Hospital X Sukabumi to the local health office.

\section{Conclusion}

Our findings help to identify the hospital responsibility towards healthcare workers 
In COVID-19 based on Indonesian Laws and Regulations and also its implementation at Hospital X Sukabumi. We collected information from different perspectives of hospital management and also healthcare workers. Data were obtained through documentary studies and in-depth interviews with key informants. Both hospital management and healthcare workers revealed that Hospital X Sukabumi has effectively implemented the laws and regulations but there are still few things that have not been fully implemented such as partially conducted education and training for healthcare workers, health improvement and recovery standards have not yet been implemented, no work nutrition, mental and spiritual and return to work program, and also the vacant position as head of HOHS unit. Hospital X Sukabumi should consider getting the implementation done because such things are crucial both for the hospital and also the healthcare workers.

\section{Bibliography}

(PERDOKI), P. S. (2020, April 6). Panduan perlindungan bagi pekerja di Fasilitas Pelayanan Kesehatan dalam masa pandemi COVID-19. Retrieved from BADAN MUTU PELAYANAN KESEHATAN: https://badanmutu.or.id/

(WHO), W. H. (2021, Februari 2). COVID-19: Occupational health and safety for health workers. Retrieved from World Health Organization: https://www.who.int/

Abbag, H. F., El-Mekki, A. A., Bshabshe, A. A., Mahfouz, A. A., Al-Dosry, A. A., Mirdad, R. T., \& Nora F AlKhttabi 7, L. F. (2018). Knowledge and Attitude Towards the Middle East Respiratory Syndrome Coronavirus Among Healthcare Personnel in the Southern Region of Saudi Arabia. Journal of Infection and Public Health, 11(5), 720-722.

Alsahafi, A. J., \& Cheng, A. C. (2016). Knowledge, attitudes, and behaviors of healthcare workers in the Kingdom of Saudi Arabia to MERS coronavirus and other emerging infectious diseases. Int J Environ Res Publ Health.13. 1214. International Journal of Environmental Research and Public Health, 13(12), 1214. doi:10.3390/ijerph13121214

Bratton, J., \& Gold, J. (1999). Human Resource Management Theory And Practice. London: Macmillan Press.

Government, I. (2009). Law Number 36 \& 44 of 2009 Concerning Health. Jakarta: State Secretariat.

Hans, K. (2006). Teori Umum Tentang Hukum dan Negara (General Theory About Law and State). Bandung: PT. Raja Grafindo Persada. 
The Implementation Effectiveness of Hospital Responsibility Towards Healthcare Workers in...

Health, M. o. (2016). Regulation of the Minister of Health of the Republic of Indonesia Number 66 of 2016 concerning Hospital Occupational Health and Safety (HOHS). Indonesia: Ministry of Health of the Republic of Indonesia.

Khalid, I., Khalid, T. J., Qabajah, M. R., Barnard, A. G., \& Qushmaq, I. A. (2016). Healthcare Worker'S Emotions, Perceived Stressors, and Coping Strategies During a MERSCoV Outbreak. Clin Med Res, 14(1), 7-14. doi:10.3121/cmr.2016.1303

Koh, D. (2020). ccupational Risks for COVID-19 Infection. Occupational Medicine, 70(1), 3-5. doi:10.1093/occmed/kqaa036

Kristiyanti, C. T. (2008). Hukum Perlindungan Konsumen (Consumer Protection Law). Jakarta: PT. Sinar Grafika.

Kusuma, S. P. (1989). Keselamatan Kerja dan Pencegahan Kecelakaan (Work Safety and Accident Prevention). Jakarta: PT. Gunung Agung.

Unhale, S. S., Ansar, Q. B., Sanap, S., Thakhre, S., Wadatkar, S., Bairagi, R., . . Biyani, K. R. (2020). A Review on Corona Virus (COVID-19). World Journal of Pharmaceutical and Life Sciences, 6(4), 109-115.

Xiaofeng, L., Zijian, F., \& Liming, L. (2020). Guidance for Corona Virus Disease 2019: Prevention, Control, Diagnosis and Management. China: People's Medical Publishing House. 